\title{
Pengaruh Pertumbuhan Ekonomi, Upah Minimum dan Pendidikan terhadap Tingkat Pengangguran di Kabupaten dan Kota Provinsi Jawa Timur Tahun 2015-2019
}

\author{
*Lailatul Hikmah, Nurul Imamah, Abdul Fattah \\ Fakultas Ekonomi dan Bisnis Universitas Bhayangkara Surabaya, Indonesia
}

DOI: $10.46821 /$ bharanomics.v2i1.187

\begin{abstract}
Abstrak
Pengangguran merupakan salah satu masalah yang sering muncul dalam proses pembangunan. Meningkatnya pengangguran bisa menjadi penghambat bagi jalanya pembangunan dan berpotensi menimbulkan masalah-masalah dalam bidang sosial maupun ekonomi.kinerja perekonomian, pendidikan, serta peran pemerintah terutama dalam kebijakan upah minimum juga menjadi salah satu faktor yang berpengaruh terhadap pengangguran. Tujuan penelitian ini adalah mengetahui pengaruh pertumbuhan ekonomi, upah minimum, dan pendidikan terhadap tingkat pengangguran di kabupaten dan kota di Jawa Timur tahun 2015-2019. Hasil dari penelitian yang dilakukan diketahui bahwa pertumbuhan ekonomi, upah minimum dan pendidikan berpengaruh signifikan secara simultan.Sedangn secara parsial diketauhi bahwa pertumbuhan ekonomi dan pendidikan berpengaruh signifikan sedangkan upah tidal berpengaruh signifikan.
\end{abstract}

Kata Kunci: Pengangguran, Pertumbuhan Ekonomi, Upah Minimum, dan Pendidikan.

\begin{abstract}
:
Unemployment is one of the problems that often arise in the development process. Mountains can be a barrier to the course of development and increase problems in the social and economic fields. Economic performance, education, and the role of the government, especially in the minimum wage policy, are also factors that influence these changes. The purpose of this study was to determine the effect of economic growth, minimum wage, and education on the level of concern in districts and cities in East Java in 2015-2019. The results of the research conducted show that economic growth, minimum wages and education have a significant effect simultaneously. While partially it is known that economic growth and education have a significant effect while wages have no significant effect.
\end{abstract}

Keywords: Unemployment, Economic Growth, Minimum Wage, and Education.

\section{PENDAHULUAN}

Sebuah Negara tidak akan lepas dari berbagai masalah yang pastinya berhubungan dengan warga negaranya. Terlebih pada Negara-negara yang memiliki jumlah penduduk yang tinggi seperti Indonesia. Adapun masalah perekonomian yang sudah tidak lazim di Indonesia adalah pengangguran. Masalah pengangguran yang di alami di Indonesia di tunjukkan dengan tingkat pengangguran terbuka dari tahun ke tahun. Terjadinya pengangguran di suatu negara dapat di karenakan jumlah lapangan pekerjaan di suatu wilayah tertentu tidak dapat mencukupi jumlah angkatan kerja atau jumlah permintaan lapangan pekerjaan akan penawaran lapangan kerja tidak seimbang. Hal tersebut berakibat bertambahnya 
jumlah pertumbuhan tenaga kerja melebihi jumlah kesempatan kerja.Indikator ekonomi yang dapat mempengaruhi besarnya tingkat pengangguran di antaranya adalah pertumbuhan ekonomi/PDRB, tingkat upah minimum dan pendidikan.Tingkat pengangguran terbuka di pulau jawa masih belum kondusif atau belum membaik, sehingga belum menunjukkan perkembangan yang signifikan dimana setiap tahunnya mengalami peningkatan dan penurunan. Laju peningkatan kesempatan kerja tidak sebanding dengan laju peningkatan pencari kerja. Pertumbuhan angkatan kerja di Jawa Timur menunjukkan peningkatan dari tahun ke tahun dan tidak dapat terserap seluruhnya di dunia kerja, sehingga menimbulkan adanya pengangguran terbuka yang jumlahnya masih mengalami peningkatan dan penurunan tiap tahunnya. Pengangguran terbuka yang tidak memiliki penghasilan akan menambahbeban keluarga dan masyarakat, kriminalitas, masalah sosial lainnya, serta kemiskinan yang tentu akan mempengaruhi stabilitas ekonomi maupun politik. Indikator selanjutnya yang berpengaruh terhadap tingkat pengangguran adalah pertumbuhan ekonomi dimana pertumbuhan ekonomi dapat mengurangi prngangguran dengan menciptakan pertumbuhan ekonomi di daerah-daerah. Menurut Sukirno (2008), pertumbuhan ekonomi adalah perkembangan kegiatan dalam pereekonomian yang menyebabkan barang dan jasa yang di produksi dalam masyarakat bertambah dan kemakmuran masyarakat meningkat.Jadi, pertumbuhan ekonomi mengukur prestasi dari perkembangan suatu perekonomian. Pertumbuhan ekonomi yang tinggi akan berdampak pada penyerapan tenaga kerja yang artinya jumlah pengangguran akan menurun. Sebaliknya jika pertumbuhan ekonomi turun maka pengangguran akan meningkat. Permasalahan utama selanjutnya dan mendasar dalam ketenagakerjaan di Indonesia adalah malasah upah.Upah yang rendah dan secara langsung dan tidak langsung berpengaruh ada tingkat pengangguran yang tinggi. Mankiw (2000), upah merupakan salah satu faktor yang mempengaruhi tingkat pengangguran.Selain itu, upah juga merupakan kompensasi yang di terima oleh satu unit tenaga kerja yang berupa jumlah uang yang di bayarkab kepadanya.Penetapan tingkat upah yang di lakukan pemerintah pada suatu Negara akann memberikan hubungan dengan besarnya tingkat pengangguran yang ada. Semakin tinggi besaran upah yang ditetapkan pemerintah maka akan berakibat pada penurunan jumlah orang yang bekerja pada Negara tersebut (Kaufman dan Hotchkis, 1999). Hal ini bisa terjadi karena dengan semakin tinggi upah yang di tetapkan maka akan berpengaruh pada peningkatan biaya output yang harus di keluarkan oleh suatu perusahaan. Akibatnya suatu perusahaan akan melakukan efesiensi terhadap produksinya dengan cara mengurangi jumlah tenaga kerja. Kenaikan upah yang terjadi akibat inflasi akan mendorong suatu perusahaan untuk mengurangi jumlah pekerjanya dalam rangka minimalisasi biaya produksi, karena upah perkerja termasuk dalam biaya produksi.Faktor pendidikan juga memiliki kontribusi dalam mempengaruhi jumlah pengangguran.Pendidikan di Provinsi Jawa timur yang di proksikan ke rata-rata lama sekolah penduduk mengalami peningkatan dari tahun ke than. Tahun 2015 rata-rata lama sekolah yang di tempuh oleh penduduk Jawa Timur yaitu sebesar 7,14 tahun dan terus mengalami peningkatan menjadi 7,39 tahun pada tahuan 2019 (BPS 2019). Menurut Kamaluddin (1999:59), semakin tinggi pendidikan seseorang makan akan tinggi pula kemampuan dan kesempatan untuk bekerja. Seseorang yang memiliki pendidikan yang tinggi cenderung memiliki kemampuan ataupun keahlian yang 
beragam sehingga akan meningkatkan kesempatan kerja dan mengurangi masalah pengangguran.

\section{TINJAUAN PUSTAKA \\ Pengangguran}

Menurut Badan Pusat statistik (BPS) dalam indikator ketenagakerjaan, pengangguran adalah penduduk yang tidak bekerja namun sedang mencari pekerjaan atau sedang mempersiapkan suatu usaha baru atau penduduk yang tidak mencari pekerjaan karena sudah di terima bekerja tetatpi belum mulai bekerja.

Menurut Sadono Sukirno (1994), pengangguran adalah suatu keadaan dimana seseorang yang termasuk dalam angkatan kerja ingin memperoleh pekerjaan akan tetapi belum mendapatkannya. Seseorang yang tidak bekerja namun tidak secara aktif mencari pekerjaan tidak tergolong sebagai pengangguran.Faktor utama yang menyebabkan terjadinya pengangguran adalah kurangnya pengeluaran agregat. Pengusaha memproduksi barang dan jasa dengan maksud memperoleh keuntungan, akan tetapi keuntungan tersebut akan diperoleh apabila pengusaha tersebut dapat menjual barang dan jasa yang mereka produksi. Semakin besar permintaan, semakin besar pula barang san jasa yang mereka wujudkan. Kenaikan produksi yang di lakukan akan menambah penggunaan tenaga kerja.

Pengangguran merupakan masalah mekaroekonomi yang mempengaruhi kelangsungan hidup manusia secara langsung.Bagi kebanyakan orang kehilangan suatu pekerjaan merupakan penurunan suatu standar kehidupan. Jadi tidak mengejutkan apabila pengangguran menjadi topic yang sering diperbincangkan dalam perdebatan politik pleh para politisi yang seringkali mengkaji bahwa kebijakan yang mereka tawarkan akan membantu terciptanya lapangan pekerjaan (Mankiw, 2000).

\section{Pertumbuhan Ekonomi}

Menurut Sandono (2008), pertumbuhan ekonomi di artikan sebagai perkembangan kegiatan dalam perekonomian yang menyebabkan barang dan jasa yang di produksi dalam masyarakat bertambah dan kemakmuran masyarakat meningkat.Dengan demikian untuk menentukan laju pertumbuhan ekonomi yang perlu dicapai dihitung adalaha pendapatan nasional rill menurut harga tetap yaitu harga berlaku di tahun dasar yang dipilih.Sehingga dapat di katakana pertumbuhan ekonomi mengukur prestasi dari perkembangan perekonomian suatu Negara. Pertumbuhan ekonomi adalh sebagian dari perkembangan kesejahteraan masyarakat yang diukur dengan besarnya pertumbuhan domestic regional bruto per kapita (PDRB per kapita ). Pertumbuhan ekonomi berarti perkembangan kegiatan dalam perekonomian yang menyebabkan barang dan jasa yang diproduksikan dalam masyarakat bertambah dan kemakmuran masyarakat meningkat (Sukirno, 1994). Pertumbuhan ekonomi diartikan sebagai kenaikan GDP (Gross Domestic Product) tanpa memandang bahwa kenaikan itu lebih besar atau lebih kecil dari pertumbuhan penduduk dan tanpa memandang apakah ada perubahan dalam stuktur ekonominya, menurut Boediono (1992), pertumbuhan ekonomi adalah suatu proses dari kenaikan output perkapita dala jangka waktu yang panjang. Pertumbuhan ekonomi disini meliputi 3 aspek yaitu: 
a. Pertumbuhan ekonomi merupakan suatu proses (aspek ekonomis) suatu perekonomian berkembang, berubah dari waktu ke waktu.

b. Pertumbuhan ekonomi berkaitan dengan adanya kenaikan output perkapita, dalam hal ini ada 2 aspek penting yaitu output total dan jumlah penduduk. Output perkapita adalah output total dibagi jumlah penduduk.

c. Pertumbuhan ekonomi dikaitkan dengan perspektif waktu jangka panjang. Dikatakan tumbuh bila dalam jangka panjang waktu waktu yang cukup lama (5 tahun) mengalami kenaikan output.

\section{Upah Minimum}

Upah adalah imbalan atas hasil kerja yang dilakukan oleh pekerja dan diberikan oleh pemilik perusahaan. Sedangkan upah sendiri memiliki titik minimum atau dikenal dengan upah minimum. Menurut peraturan pemerintah Nomer 78 Tahun 2015 Pasal 41, menjelaskan arti upah minimum yaitu upah terkecil yang dimana terdiri atas upah pokok maupun upah tanpa tunjangan. Upah minimum sendiri dibedakan menjadi dua berdsarkan wilayah yaitu Upah Minimum Kota/Kabupaten (UMK) dan Upah Mnimum Provinsi (UMP). Dalam setiap provinsi maupun kabupatenn upah yang diberikan dari perusahaan berbeda-beda tergantung dari masing-masing daerah tersebut. Besaran UPM ditentukan oleh gubernur masing-masing provinsi, karena kebutuhan hidup di setiap provinsi berbeda-beda. Secara teoritis besaran upah minimum ditentukan oleh Kebutuhan Fisik Minimum (KFM), Indeks Harga Konsumen (IHK) dan Pertumbuhan Ekonomi Daerah (Sumarsono, sonny, 2009). Menurut Trianggono dan Siti Umajah (2017), penetapan tingkat upah yang dilakukan oleh pemerintah berdasarkan usulan atau masukan dari komisi pengupahan dan jaminan sosial dari dewan ketenagakerjaan daerah tentang keharusan perusahaan untuk membeyarkan sekurang-kurangnya sejumlah upah kepada pekerja yang paling rendah tingkatnya.

\section{Pendidikan}

Menurut Todaro (2004), bahwa permintaan pendidikan di pengaruhi oleh dua hal, pertama harapan seorang siswa yang lebih terdidik untuk mendapatkan pekerjaan yang lebih baik layak pada era modern dimana dimasa yang akan dating bagi siswa itu sendiri ataupun keluarganya serta biaya pendidikan naik bersifat langsung ataupun tidak langsung akan ditanggung oleh siswa dan keluarganya. Yang kedua, dari sisi penawaran jumlah sekolah di tingkat sekolah dasar, menengah, dan universitas lebih banyak ditemukan oleh proses politik yang sering tidak berkaitan dengan kriteria ekonomi. Peningkatan kualitas sumber daya manusia merupakan upaya peningkatan kualitas pengembangan aktivitas dalam bidang pendidikan dan pelatihan. Pendidikan merupakan sarana untuk mengembangkan kecerdasan, kemampuan serta keterampilan, melalui pendidikan yang lebih baik. Kemampuan dasar yang di peroleh dalam proses pembelajaran adalah kemampuan baca tulis. Salah satu indikator yang digunakan untuk mengukur kemampuan baca tulis adalah angka melek huruf.Angka melek huruf dihitung dari perbandingan penduduk berusia 15 tahun (BPS Prov. DIY).

\section{KERANGKA KONSEPTUAL}

Atas dasar pemikiran dan beberap hasil penelitian terdahulu mengenai berbaga hubungan antara variable independen (Pertumbuhan Ekonomi, Upah Minimum 
dan Pendidikan) dengan variable dependen (Tingkat Pengangguran), sebagaimana dijelaskan diatas dan disesuaikan dengan kondisi yang ada di Kabupaten dan Kota Provinsi Jawa Timur dari tahun 2015-2019 maka faktorfaktor yang mempengaruhi banyaknya tingkat pengangguran 38 Kabupaten dan Kota Provinsi Jawa Timur dapat di gambarkan sebagai berikut (Gambar 1).

\section{METODE PENELITIAN}

Penelitian merupakan penelitian kuantitatif dengan menggunakan data sekunder yang diperoleh dari situs Pusat Badan Statistik tahun 2015-2019. Pengampbilan sampel pada penelitian ini adalah Disproportionate Startifed Random Sampling. Sampel yang diambil dari penelitian ini adalah berkaitan dengan seluruh penduduk yang ada di kabupaten dan kota di Jawa Timur, meliputi pertumbuhan ekonomi, upah minimum dan pendidikan periode 2015-2019.Variabel dependen dalam penelitian ini adalah pengangguran dan variable independen meliputi pertumbuhan ekonomi, upah minimum dan pendidikan.angka-angka tersebut diperoleh dari data yang sudah ada dan dibuat daftarnya didalam program Microsoft Excel sebelum dignakan dalam pengujian statistik.

\section{HASIL DAN PEMBAHASAN}

\section{Uji Normalitas}

Uji normalitas bertujuan untuk mengetahui apakah variabel penganggu atau residual memiliki distribusi normal.Uji normalitas dapat dilakukan dengan pengujian statistik non-paramertik Kolmogrov-Smirnov $(K-S)$. Jika signifikan diatas 0,05 maka tidak terdapat perbedaan yang signifikan antara data yang akan diuji dengan data normal baku, artinya data tersebut normal (Tabel 1).

Dari hasil pengujian normalitas dengan uji Kolmogorov-Smirnov diperoleh nilai taraf kemaknaan uji Asymp. Sig (2-tailed) sebesar 0,200 (p = 0,200 ). Karena $\mathrm{p}=0,200>\alpha=0,05$ maka hasil uji Kolmogorov-Sminov memberikan kesimpulan bahwa $\mathrm{H}_{0}$ diterima yang berarti data berdistribusi normal.

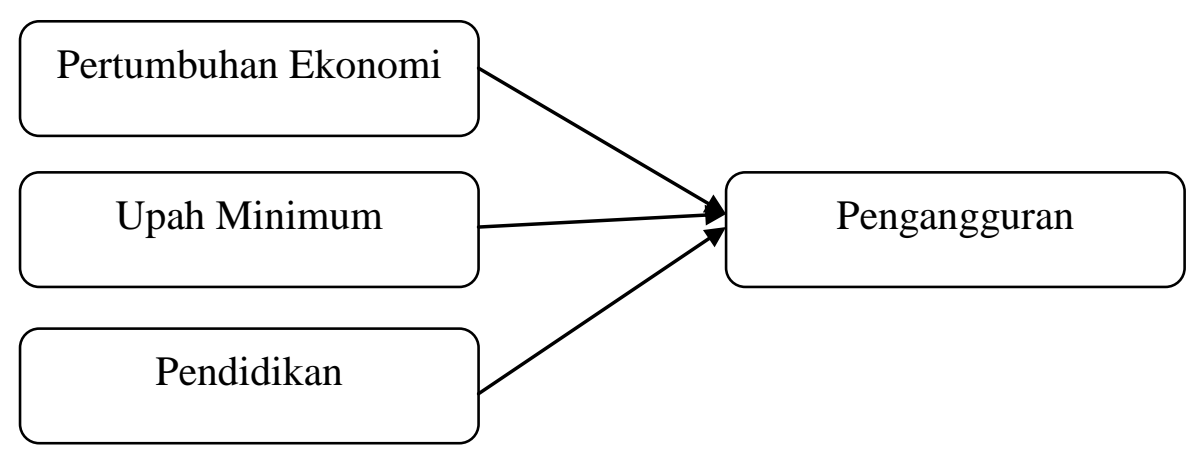

\section{Gambar 1. Kerangka Konseptual}

Sumber : Peneliti (2021) 
Tabel 1

Uji Normalitas

One-Sample Kolmogorov-Smirnov Test

\begin{tabular}{lll}
\hline & & Unstandardized Residual \\
\hline $\mathrm{N}$ & & 190 \\
Normal Parameters & Mean & .0000000 \\
& Std. Deviation & 1.14047961 \\
Most Extreme Differences & Absolute & .055 \\
& Positive & .055 \\
& Negative & -.041 \\
Test Statistic & & .055 \\
Asymp. Sig. (2-tailed) & & $.200^{\mathrm{c}, \mathrm{d}}$ \\
\hline
\end{tabular}

Sumber: Hasil data yang diolah peneliti (2021)

Tabel 2

Uji Multikolenieritas

\begin{tabular}{lcc}
\hline \multirow{2}{*}{ Model } & \multicolumn{2}{c}{ Collinearity Statistics } \\
\cline { 2 - 3 } & Tolerance & VIF \\
\hline constan & & \\
pertumbuhan ekonomi & 0.564 & 1.773 \\
upah minimum & 0.491 & 2.037 \\
pendidikan & 0.832 & 1.203 \\
\hline
\end{tabular}

Sumber: Hasil data yang diolah peneliti (2021)

\section{Uji Multikolenearitas}

Uji multikolinieritas digunakan untuk mengetahui ada atau tidaknya penyimpangan asumsi klasik .uji multikolinieritas bertujuan untuk menguji apakah model regresi ditemukan adanya kolerasi antar variabel bebas.

Berdasarkan tabel 2 dapat dilihat bahwa nilai tolerance tiap variabel lebih besar dari 0,1 dan nilai VIF lebih kecil dari 10,00 maka dapat disimpulkan tidak terjadi gejala multikoleneritas antar variabel bebas dalam penelitian.

\section{Uji Heteroskedastisitas}

Uji heterokedastisitas untuk mengetahui apakah dalam sebuah model regresi terjadi ketidaksamaan varians dari residual suatu pengamatan ke pengamatan lain. Jika varians dari residual suatu pengamatan ke pengamatan lain tetap disebut homoskedastisitas untuk penelitian ini menggunakan uji scatterplot. 


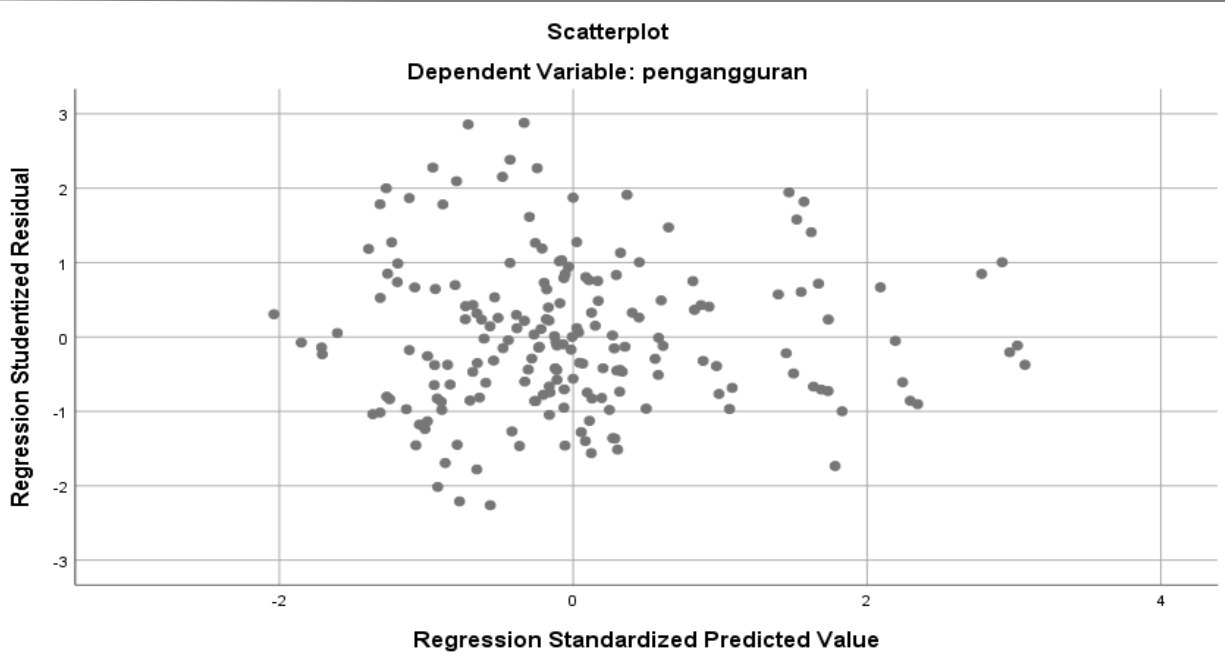

Gambar 2

Uji Heroskedastisitas

Sumber: Hasil data yang diolah peneliti (2021)

Tabel 3

Uji Autokorelasi

Model Summary ${ }^{b}$

\begin{tabular}{cccccc}
\hline Model & $\mathrm{R}$ & R Square & $\begin{array}{c}\text { Adjusted R } \\
\text { Square }\end{array}$ & $\begin{array}{c}\text { Std. Error of } \\
\text { the Estimate }\end{array}$ & $\begin{array}{c}\text { Durbin- } \\
\text { Watson }\end{array}$ \\
\hline 1 & $.552^{\mathrm{a}}$ & .305 & .294 & 1.14964 & .823 \\
\hline
\end{tabular}

a. Predictors: (Constant), pendidikan, pertumbuhan ekonomi, upah minimum

b. Dependent Variabel: pengangguran

Sumber: Hasil data yang diolah peneliti (2021)

Tabel 4

Uji Autokorelasi

Model Summary ${ }^{\mathrm{b}}$

\begin{tabular}{cccccc}
\hline Model & $\mathrm{R}$ & R Square & Adjusted R Square & $\begin{array}{c}\text { Std. Error of the } \\
\text { Estimate }\end{array}$ & $\begin{array}{c}\text { Durbin- } \\
\text { Watson }\end{array}$ \\
\hline 1 & $.474^{\mathrm{a}}$ & .225 & .212 & .89587 & 1.836 \\
\hline
\end{tabular}

a. Predictors: (Constant), Lag_x3, Lag_x1, Lag_x2

b. Dependent Variabel: Lag_y1

Sumber: Hasil data yang diolah peneliti (2021)

Berdasarkan gambar 2, antara nilai prediksi variabel terikat (Dependent Vrable) dengan residualnya diperoleh hasil tidak adanya pola yang jelas dan titiktik menyebar diatas dan dibawah angka 0 pada sumbu Y, maka tidak terjadi heteroskedastisitas. 


\begin{tabular}{|c|c|c|c|c|c|c|}
\hline \multicolumn{7}{|c|}{$\begin{array}{c}\text { Tabel } 5 \\
\text { Regresi Linear Berganda } \\
\text { Coefficients }^{\mathrm{a}}\end{array}$} \\
\hline \multirow[b]{2}{*}{ Model } & & \multicolumn{2}{|c|}{$\begin{array}{l}\text { Unstandardized } \\
\text { Coefficients }\end{array}$} & $\begin{array}{c}\text { Standardized } \\
\text { Coefficients }\end{array}$ & \multirow[b]{2}{*}{$\mathrm{T}$} & \multirow[b]{2}{*}{ Sig. } \\
\hline & & $\mathrm{B}$ & Std. Error & Beta & & \\
\hline 1 & (Constant) & -4.657 & 4.907 & & -.949 & .344 \\
\hline & pertumbuhan ekonomi & .447 & .114 & .318 & 3.909 & .000 \\
\hline & upah minimum & .115 & .398 & .025 & .289 & .773 \\
\hline & Pendidikan & .327 & .056 & .393 & 5.865 & .000 \\
\hline
\end{tabular}

a. Dependent Variabel: pengangguran

Sumber: Hasil data yang diolah peneliti (2021)

\section{Uji Autokorelasi}

Pengujian autokorelasi dilakukan untuk mengetahui terdapat tidaknya autokorelasi berantai diantara faktor-faktor yang mengganggu secara berurutan. Dalam penelitian ini, metode pengujian dengan menggunakan nilai Durbin Watson (DW).

Berdasarkan tabel 3, hasil uji autokorelasi dengan metode Durbin Watson, diperoleh dilai DW hitung sebesar 0,823. Dan diperoleh nilai dalam tabel DW untuk $(\mathrm{k}=3)$ dan $(\mathrm{n}=190)$ adalah sebesar nilai dL (batas bawa) sebesar 1,7306 dan nilai dU (batas atas) sebesar 1,7947.

Berdasarkan pedoman uji statistik Durbin Watson, maka dapat dilihat bahwa nilai DW hitung terletak diantara $(0<\mathrm{d}<\mathrm{dL})$, yaitu sebesar $0<0,823<$ 1,7306. Maka dapat disimpulkan bahwa data yang digunakan tidak ada autokorelasi positif.Untuk dapat memenuhi uji asumsi klasik yang berupa uji autokorelasi, maka perlu diperlukan transformasi data dalam bentuk Lagres ( Lag) (Tabel 4).

\section{Regresi Linear Berganda}

Berdasarkan hasil perhitungan regresi pada tabel 5 diperoleh persamaan sebagai berikut:

Pengangguran $=(-4.657)+0,447 \mathrm{X}_{1}+0.115 \mathrm{X}_{2}+0.327 \mathrm{X}_{3}$

Persamaan diatas dapat diartikan sebagai berikut :

a. Nilai konstan pada angka -4.657 yang artinya jika variabel pertumbuhan ekonomi, upah minimum dan pendikan $=0$ maka $\mathrm{Y}=-4.657$

b. Variabel pertumbuhan ekonomi mempunyai koefesien regresi sebesar 0.447 maka artinya setiap 1 satuan nilai variabel pertumbuhan ekonomi $\left(\mathrm{X}_{1}\right)$ akan bertambahnya nilai pengangguran (Y) sebesar 0.447 .

c. Variabel upah minimum mempunyai koefisien regresi sebesar 0.115 maka artinya setiap 1 satuan nilai variabel upah minimum $\left(\mathrm{X}_{2}\right)$ akan bertambahnya nilai pengangguran $(\mathrm{Y})$ sebesar 0.115 .

Variabel pendidikan mempunyai koefisien regresi sebesar 0.327 maka artinya setiap satu satuan nilai variabel upah minimum $\left(\mathrm{X}_{3}\right)$ akan bertambahnya nilai pengangguran $(\mathrm{Y})$ sebesar 0.327 . 


\begin{tabular}{|c|c|c|c|c|c|c|}
\hline & & $\begin{array}{r}\mathbf{T} \\
\mathbf{U j i} \\
\mathbf{A}\end{array}$ & $\begin{array}{l}6 \\
\text { ultar } \\
\mathrm{VA}^{\mathrm{a}}\end{array}$ & & & \\
\hline Model & & Sum of Squares & Df & Mean Square & $\mathrm{F}$ & Sig. \\
\hline 1 & Regression & 107.931 & 3 & 35.977 & 27.221 & $.000^{\mathrm{b}}$ \\
\hline & Residual & 245.831 & 186 & 1.322 & & \\
\hline & Total & 353.762 & 189 & & & \\
\hline
\end{tabular}

Sumber: Hasil data yang diolah peneliti (2021)

Tabel 7

Uji Parsial

Coefficients $^{\mathrm{a}}$

\begin{tabular}{|c|c|c|c|c|c|}
\hline \multirow[b]{2}{*}{ Model } & \multicolumn{2}{|c|}{$\begin{array}{l}\text { Unstandardized } \\
\text { Coefficients }\end{array}$} & \multirow{2}{*}{$\begin{array}{c}\begin{array}{c}\text { Standardized } \\
\text { Coefficients }\end{array} \\
\text { Beta }\end{array}$} & \multirow[b]{2}{*}{$\mathrm{t}$} & \multirow[b]{2}{*}{ Sig. } \\
\hline & $\mathrm{B}$ & Std. Error & & & \\
\hline $1 \quad$ (Constant) & -4.657 & 4.907 & & -.949 & .344 \\
\hline pertumbuhan ekonomi & .447 & .114 & .318 & 3.909 & .000 \\
\hline upah minimum & .115 & .398 & .025 & .289 & .773 \\
\hline pendidikan & .327 & .056 & .393 & 5.865 & .000 \\
\hline
\end{tabular}

a. Dependent Variabel: pengangguran

Sumber: Hasil data yang diolah peneliti (2021)

\section{UJI HIPOTESIS}

\section{Uji Simultan}

Uji $\mathrm{F}$ digunakan untuk menunjukkan apakah keseluruhan variabel independen berpengaruh terhadap variabel dependen dengen menggunakan level of significance 5\%. Berdasarkan tabel 6, maka dapat diketahui bahwa variabel independen pertumbuhan ekonomi, upah minimum dan pendidikan secara simultah berpengaruh secara signifikan terhadap variabel dependen yaitu tingkat pengangguran. Hal ini di buktikan dengan $F_{\text {hitung }}$ sebesar 27,221 dan nilai $F_{\text {tabel }}$ sebesar 3,04 dimana diketahui $F_{\text {hitung }} \geq F_{\text {tabel, }}$ dengan nilai signifikansi $0,000<$ 0,05 sehingga artinya semua variabel independen secara simultan berpengaruh positif dan signifikan terhadap variabel dependen.

\section{Uji Parsial}

Uji t merupakan uji signifikan pengaruh setiap variabel antara variabel independen terhadap variabel dependen. Dengan demikian melalui uji t akan diketahui bagaimana pengaruh variabel independen secara parsial terhadap tingkat pengangguran di Propinsi Provinsi Jawa Timur (Tabel 7).

Uji t merupakan uji signifikan pengaruh setiap variabel antara variabel independen terhadap variabel dependen. Dengan demikian melalui uji t akan diketahui bagaimana pengaruh variabel independen secara parsial terhadap tingkat pengangguran di Propinsi Provinsi Jawa Timur.

Dengan nilai $\mathrm{t}_{\text {tabel }}=1,659$, jika $\mathrm{t}_{\text {hitung }}>\mathrm{t}_{\text {tabel }}=$ maka $\mathrm{H}_{\mathrm{O}}$ ditolak artinya secara parsial variabel independen berpengaruh terhadap variabel dependen dan jika $\mathrm{t}_{\text {hitung }}<\mathrm{t}$ tabel $=$ maka $\mathrm{H}_{\mathrm{O}}$ diterima maka artinya secara parsial variabel independen tidak berpengaruh terhadap variabel dependen. 


\section{Tabel 8}

\section{Uji Dominan}

\begin{tabular}{llccc}
\hline & & & & Standardized \\
Model & & B & Std. Error & Beffandardized Coefficients \\
\cline { 2 - 4 } & & -4.657 & 4.907 & \\
& (Constant) & .447 & .114 & .318 \\
& pertumbuhan ekonomi & .115 & .398 & .025 \\
& upah minimum & .056 & .393 \\
pendidikan & .327 & .056 & \\
\hline
\end{tabular}

Sumber: Hasil data yang diolah peneliti (2021)

a. Hasil Pengujian Hipotesis Pertumbuhan Ekonomi

Hasil pengujian hipotesis pertumbuhan ekonomi menunjukkan bahwa jika $t_{\text {hitung }}>$ $\mathrm{t}_{\text {tabel }}=3,909>1,659$ maka $\mathrm{H}_{\mathrm{O}}$ ditolak. Dengan nilai signifikan $0,000<0,05 \mathrm{Hal}$ ini berarti $\mathrm{H}_{\mathrm{O}}$ ditolak dan $\mathrm{H} \alpha$ diterima. Jadi dapat disimpulkan bahwa pertumbuhan ekonomi berpengaruh dan signifikan terhadap tingkat pengangguran di Provinsi Jawa Timur.

b. Hasil Pengujian Hipotesis Upah Minimum

Hasil pengujian hipotesis upah minimum menunjukkan bahwa jika $\mathrm{t}_{\text {hitung }}<\mathrm{t}_{\text {tabel }}$ $=0,289<1,659$ maka $\mathrm{H}_{\mathrm{O}}$ diterima. Dengan nilai signifikan 0,773 >0,05 Hal ini berarti $\mathrm{H}_{\mathrm{O}}$ diterima dan $\mathrm{H} \alpha$ ditolak. Jadi dapat disimpulkan bahwa upah minimum tidak berpengaruh berpengaruh dan tidak signifikan terhadap tingkat pengangguran di Provinsi Jawa Timur.

c. Hasil penhujian hipotesis pendidikan

Hasil pengujian hipotesis pendidikan menunjukkan bahwa jika $\mathrm{t}_{\text {hitung }}>\mathrm{t}_{\text {tabel }}=$ $5,865>1,659$ maka $\mathrm{H}_{\mathrm{O}}$ ditolak. Dengan nilai signifikan 0,000 $<0,05 \mathrm{Hal}$ ini berarti $\mathrm{H}_{\mathrm{O}}$ ditolak dan $\mathrm{H} \alpha$ diterima. Jadi dapat disimpulkan bahwa pendidikan berpengaruh dan signifikan terhadap tingkat pengangguran di Provinsi Jawa Timur.

\section{Uji Dominan}

pengujian dominan pada temuan lain menunjukkan bahwa ada salah satu diantara variable bebas, yaitu pertumbuhan ekonomi, upah minimum dan pendidikan terhadap tingkat pengangguran. Berdasarkan tabel 8, maka dijelaskan bahwa hasil analisis koefesien regresi menunjukkan angka-angka koefesien yang belum standar (B) sehingga perlu dilakukan penentuan pada nilai koefisien yang distandarkan (Beta), dimana ditunjukkan dari besarnya masing-masing variable bebas, yaitu : pertumbuhan ekonomi, upah minimum, dan pendidikan mempunyai pengaruh dominan terhadap tingkat pengangguran di Provinsi Jawa Timur yang memiliki nilai standardized coefficients atau koefisien standar (Beta) memiliki nilai koefisien terbesar adalah variable pendidikan yang besarnya 0,393. Jadi temuan lain dari penelitian ini menyatakan bahwa variable pendidikan mempunyai pengaruh dominan terhadap kepuasan pelanggan. 


\section{SIMPULAN}

Berdasarkan uraian pada latar belakang, rumusan masalah, pengujian data, hipoteis, penelitian terdahulu, teori, hasil regresi linear berganda dan pembahasan diperoleh kesimpulan sebagai berikut, 1) Pertumbuhan ekonomi, upah minimum dan pendidikan secara simultan berpengaruh signifikan terhadap tingkat pengangguran. Hasil ini menunjukkan bahwa hipotesis terbukti kebenarannya. 2) Pertumbuhan ekonomi, dan pendidikan secara parsial berpengaruh signifikan terhadap tingkat pengangguran. Sedangkan upah minimum secara parsial tidak berpengaruh terhadap tingkat pengangguran. 3) Pendidikan mempunyai pengaruh dominan terhadap tingkat pengangguran. Sedangkan, hipotesis yang diajukan bahwa pertumbuhan ekonomi berpengaruh dominan terhadap tingkat pengangguran di kabupaten dan kota provinsis jawa timur tahun 2015-2019. Hasil ini menunjukkan bahwa hipotesis terbukti karena secara umum pertumbuhan ratarata lama sekolah dikabupaten dan kota provinsi Jawa Timur mengalami peningkatan tetapi peningkatan tersebut cenderung akan meningkatkan jumlah pengangguran yang ada. Kondisi ini terjadi pada jawa timur karena secara umum pertumbuhan rata-rata lama sekolah masih cenderung di angkat 7,5 tahun atau setara dengan SMP. Capaian rata-rata lama sekolah yang hanya sampai SMP akan sulit memasuki dunia kerja yang membutuhkan pekerja dengan memiliki keahlian dan rata-rata lama sekolah minimal 12 tahun atau lebih sehingga akan menimbulkan jumlah pengangguran meningkat. Kondisi ini sejalan dengan penelitian yang dilakukan oleh Edy (2009) di Jawa Tengah dan Subaidah dan Cahyono (2013) menyimpulkan bahwa pendidikan memiliki hubungan positif dan signifikan dikarenakan seseorang yang memiliki rata-rata lama sekolah yang tinggi akan cenderung untuk lebih menseleksi pekerjaan yang sesuai dengan bidang dan keahliann seseorang tersebut.

\section{DAFTAR PUSTAKA}

Boediono. 1992. Teori Pertumbuhan Ekonomi. Yogyakarta, BPFE UGM.

Kartonegoro, S. 2000. Analisa dan Menejemen Investasi. Edisi Pertama. Jakarta: PT. Wisdya Press.

Kaufman, Bruce E. and Julie L. Hotchkiss. 1999. The Economic Labor Markets. USA: Georgia State University.

Mankiw, 2000. Makroekonomi Edisi ke Enam, Erlangga, Jakarta.

Sadono, S. 1994. Pengantar Ekonomi Makro. PT. Raja Grasindo Persada. Jakarta.

Sadono, S. 2008. Mikroekonomi: Teori Pengantar. Edisi Ketiga. Jakarta: PT Raja Grafindo Persada.

Todaro, M. 2004. Pembangunan Ekonomi di Dunia Ketiga. Penerbit Erlangga Edisi Kedelapan, 2004.

Kamaluddin, R. 1999. Pengantar Ekonomi Pembangunan. Jakarta: Lembaga Pernerbit Fakultas Ekonomi Universitas Indosia. 